\title{
Residential Context and Voting for the Far Right: The Impact of Immigration and Unemployment on the 2017 French Presidential Election
}

\author{
Pavlos Vasilopoulos $^{1}$ (D) Haley McAvay ${ }^{2}$ (D) Sylvain Brouard ${ }^{3}$
}

Accepted: 11 January 2021 / Published online: 3 February 2021

(c) The Author(s) 2021

\begin{abstract}
The assumption that increasing diversity and economic hardship boost support for the far right is widespread, yet extant research comes up with contradictory findings. This article investigates the link between context and the far right by investigating the impact of immigration and unemployment on voting for Marine Le Pen in the first round of the 2017 French Presidential election. We match a large individuallevel survey with contextual variables constructed from the census describing voters' residential environments. Unlike previous studies, we measure immigration and unemployment at the neighborhood level and the broader level of the department. Using a multilevel model, we find that voters in neighborhoods with high levels of immigration are less likely to vote for the far right. However, in departments, increased immigration and unemployment correlate with greater support for Le Pen. These findings suggest that contact theory and ethnic threat operate differently according to spatial scale.
\end{abstract}

Keywords Contact theory $\cdot$ Ethnic threat $\cdot$ Neighborhoods $\cdot$ Extreme voting $\cdot$ Front National

Haley McAvay

haley.mcavay@york.ac.uk

Pavlos Vasilopoulos

pavlos.vasilopoulos@york.ac.uk

Sylvain Brouard

sylvain.brouard@sciencespo.fr

1 Department of Politics, University of York, Heslington Lane, York YO10 5DD, UK

2 Department of Sociology, University of York, 292 Wentworth Way, Heslington, York YO10 5NG, UK

3 Cevipof, 98 rue de l'Université, 75007 Paris, France 


\section{Introduction}

It is a commonly held assumption that the increased presence of immigrants in European societies has in part spurred the success of the far right, particularly in times of economic crisis. In line with this assumption, a broad stream of research has investigated the role of contextual characteristics in political choice, focusing specifically on how indicators such as immigrant shares or unemployment rates correlate with the success of anti-immigrant parties (Arzheimer 2009; Arzheimer and Carter 2006; Dinas and van Spanje 2011; Enos 2017; Georgiadou et al. 2018; Halla et al. 2017; Knigge 1998; Savelkoul et al. 2017; Scheepers et al. 2002; Scheve and Slaughter 2001; Wagner et al. 2006).

Yet, despite this widespread conviction, there is still little agreement regarding which spatial features drive the far-right vote or the influence that these features have. For instance, a recent meta-analysis found that out of a total of 291 tests of the association between immigration shares and far-right voting at the sub-national level, $36 \%$ of the analyses report a positive effect, $14 \%$ a negative effect, while the rest of the studies find no association (Amengay and Stockemer 2018). A similar meta-analysis found that the effect of unemployment on support for the far right was also inconsistent across studies (Sipma and Lubbers 2018).

These discrepancies stem in part from competing theoretical expectations, but they are also rooted in diverging methodological choices that characterize this stream of research. Most studies only rely on macro-level data. Although useful for documenting associations between contextual characteristics and voting patterns, macro approaches cannot establish whether neighborhood factors such as immigration are a significant predictor of individual voting behavior net of sociodemographics that sort people into residential locations. Moreover, the spatial scales at which contextual characteristics are measured vary considerably, from national to regional to departmental levels, and rarely do studies investigate these effects at small spatial scales or account for multiple scales at once.

In this article, we aim to increase the current understanding of the link between spatial characteristics and the far right by investigating the impact of local immigration and unemployment on voting for Marine Le Pen in the first round of the 2017 French Presidential election. To this end, using geographic ID codes, we match a large $\mathrm{N}$ individual-level survey with contextual variables constructed from the census describing voters' residential environments. ${ }^{1}$ Unlike previous studies that rely on ecological data at large levels of aggregation, we measure immigration and unemployment at the smallest available spatial scale in French data, the neighborhood ("IRIS"), as well as the broader level of the department, using a multilevel model. Indeed, we find contrasting associations between context and far-right voting depending on the spatial unit. Specifically, we find that, in line with contact theory, voters in neighborhoods with high levels of immigration are less likely to vote for

\footnotetext{
1 Replication files can be accessed at: https://dataverse.harvard.edu/dataset.xhtml?persistent Id=doi:10.7910/DVN/NPONP6.
} 
the far right, while at the same time, increased immigration and unemployment at the department level correlate with an increased support for Le Pen.

These findings contribute to the literature on residential context and far-right voting in three ways. First, we offer an assessment of contextual effects at the local level by examining how far-right voting varies across neighborhoods. While recent studies have explored neighborhood-level variation in far-right voting, these have relied on aggregate level data only (Steinmayr 2016; Halla et al. 2017). Second, we assess the effect of the neighborhood immigrant share and unemployment rate on individual voting behavior net of social and demographic characteristics, attitudes, and other geographic controls. Because we account for individual characteristics that influence both the likelihood of voting for the far right and residential location (i.e. educational levels or immigrant origin), our model provides a more robust estimate of the effect of neighborhoods ceteris paribus than studies relying on aggregate-level data. Third, by integrating two spatial levels into the analysis, we show that the effects of immigration and unemployment vary according to scale.

\section{Theoretical Perspectives on Context and Far-Right Voting}

The most common theoretical perspectives on the association between contextual characteristics and the vote are economic competition, contact theory, and ethnic threat. The economic competition hypothesis (Scheepers et al. 2002) posits that economic hardship in a residential environment should increase competition between natives and immigrants over scarce resources such as jobs, benefits, or public housing. Consequently, this competition will render voters more susceptible to the antiimmigrant platform of the far right that typically places special emphasis on the negative economic impacts of immigration. The most commonly used aggregate index to test the economic competition hypothesis is the level of unemployment at the national or subnational level (Amengay and Stockemer 2018; Golder 2003; Jackman and Volpert 1996; Knigge 1998; Lubbers and Scheepers 2002). However, empirical support for the economic threat hypothesis is inconclusive given several contradictory findings (Amengay and Stockemer 2018; Arzheimer and Carter 2006; Knigge 1998; Lubbers and Scheepers 2002). Some studies document a positive effect of unemployment on the far-right vote (Arzheimer 2009; Jackman and Volpert 1996; Lubbers and Scheepers 2000), while others find no association (Golder 2003; Green et al. 2016), and still others report a negative effect (Lubbers et al. 2002).

Whereas the economic competition hypothesis attempts to explain far-right voting based on material concerns, the mechanisms central to contact theory and ethnic threat relate to the mere presence of immigrants and ethnic minorities in a locality regardless of economic conditions. Several research programs draw on the premises of intergroup contact theory (Allport 1954; Pettigrew 1998) to argue that living in proximity to ethnic minorities and immigrants creates opportunities for interaction that increase inter-group tolerance, which in turn translates into lower support for anti-immigrant parties (Jolly and DiGiusto 2014; Wagner et al. 2006). These studies therefore predict a negative relationship between immigrant presence and farright voting. In contrast, ethnic threat posits that the presence of ethnic minorities 
in a local population triggers cultural and ethnic resentment (Anderson 1996; Coffé et al. 2007; Knigge 1998; Halla et al. 2017; Hangartner et al. 2019; Savelkoul et al. 2017). Vote shares for the far right should hence be higher in areas with larger shares of immigrants, as voters will turn to anti-immigration parties because they feel that immigration threatens their cultural values, national identity, and the ethnic homogeneity of the country (Lucassen and Lubbers 2012).

Some research in this vein points out that contact mechanisms or ethnic threat may not be triggered by minority group size alone. According to the salience-ofchange hypothesis, Newman and Velez (2014) instead argue that citizens are sensitive to the growth over time of local immigrant populations rather than overall levels of immigrants. Empirically, this hypothesis calls for studies that test how farright voting changes in reaction to fluctuations in local composition, such as sudden inflows of migrants into a neighborhood (Steinmayr 2016; Halla et al. 2017). Further, the nature of geographical proximity between immigrants and natives may be different in such cases of rapid population change, especially when inflows are temporary, as in the case of refugee arrivals. In such cases, even if exposure to migrants in the local area occurs, sustained contact that would foster in-group/ out-group interaction and tolerance may not necessarily take place (Hangartner et al. 2019). As is the case with levels of unemployment, the empirical literature documents contrasting associations between levels of (or changes in) immigration and the far-right vote, varying from positive, negative or even no effects (Amengay and Stockemer 2018). In Belgium, Coffé et al. (2007) find a positive association between the number of immigrants at the municipality level and aggregate support for the far right, suggesting ethnic threat mechanisms. Similarly, in their analysis that matches individual-level data with the share of immigration at the neighborhood level, Savelkoul et al. (2017) illustrate a positive correlation between levels of immigration and voting for the far-right PVV, finding at the same time that interethnic contact plays a minimal role. Hangartner et al. (2019) report that refugee arrivals increased outgroup prejudice among the populations of the East Aegean Greek islands that experienced significant refugee inflows. On the other hand, drawing on Swiss survey data, Green et al. (2016) find evidence of contact theory in terms of self-reported interactions with immigrants, but still find that an increase of the immigrant share at the extra-local level bolsters ethnic threat. Even similar aggregate-level analyses from the same national context produce contrasting results: while Steinmayr (2016) shows that support for the far-right Austrian Freedom Party drops as refugee inflows into neighborhoods rise, indicating contact theory, Halla et al. (2017) find evidence of ethnic threat as immigrant shares increase.

\section{Variations According to Spatial Scale}

One way of understanding these seemingly contradictory findings is to consider variations related to spatial scale. Extant literature typically draws on data that measure contextual characteristics at broad aggregate levels, such as municipalities (Dinas and Van Spanje 2011), departments (Lubbers and Scheepers 2000, 2002; Rojon 2013), regions (Jolly and DiGiusto 2014; Georgiadou et al. 2018), or even the whole 
country (Arzheimer 2009; Golder 2003; Knigge 1998; Lubbers et al. 2002; Lucassen and Lubbers 2012; Van der Brug et al. 2005).

Yet, these varying scales of aggregation could be capturing different social processes impacting the vote (Della Posta 2013). Contact theory assumes that proximity to immigrants matters because frequent direct interactions dampen fears about the potential negative economic or cultural repercussions brought on by migration. Therefore, contact theory operates specifically at a local level, and its effect should only be observed when immigrant shares and voting behavior are compared at the neighborhood level.

On the other hand, if contact exists at the local level, ethnic threat might still be observed at the extra-local level. Some studies argue over the existence of a 'halo effect', according to which the propensity to vote for far-right parties increases in places near immigrant-dense areas rather than within the areas themselves (Perrineau 1997; Rydgren and Ruth 2013 but see Rydgren and Tyrberg 2020). This means that voters may feel hostility towards immigrants regardless of whether they have frequent contact with these groups in their neighborhoods. The local media in departments or regions with high levels of immigration likely plays a role by promoting negative representations of immigration, crime and economic insecurity in an area, which heighten the salience of immigration and feelings of threat (Rojon 2013; Green et al. 2016; Della Posta 2013).

Further, residential mobility dynamics may produce ethnic threat processes that are only observable at extra local scales. Research into white flight has documented that white households move out of local areas when the immigrant population reaches a certain threshold (Schelling 1969). These mobility patterns may be sustained in part by groups with low tolerance to ethnic diversity whose support for anti-immigrant parties would likely be bolstered by the sentiment of having been "pushed out" of their residential areas by increasing numbers of immigrants. The relocation of extreme voters in the outskirts of large cities with high immigrant shares could produce ethnic threat at the broader level of the department or region. This would not exclude the possibility that contact mechanisms are still at play in local spaces with high shares of immigrants.

A few studies compare contact theory and ethnic threat at different spatial scales. Della Posta (2013) finds a positive association between department-level Front National vote shares in France and the foreign-born population share. However, this association is inversed when the smaller municipality level is examined. Similarly, Rojon (2013) shows evidence of ethnic threat in rural areas but not in urban areas. The importance of level of aggregation also emerges from the results of Green et al. (2016), who find simultaneous evidence of extra local ethnic threat and the attenuation of far-right voting through interpersonal contact.

However, none of these studies use combined individual and neighborhood-level data to estimate contextual effects net of individual characteristics. This is a crucial point given that individuals who move into immigrant areas tend to be demographically or culturally selected, i.e. they have characteristics that make them more favorable to immigrants and less likely to vote for the far right. For instance, people with high education and high socioeconomic status are more likely to be favorable towards immigration, less likely to vote for anti-immigrant parties and more likely 
to live in cities where immigrants are present (Kaufmann and Harris 2015; Maxwell 2019). Our approach thus provides a more accurate estimate of the role of the neighborhood and department ceteris paribus.

Finally, economic competition may also play out differently according to spatial scale. As individuals have access to job markets that transcend the borders of their local residential area, competition between natives and immigrants for jobs or other resources likely occur at larger scales than the neighborhood. No studies to our knowledge compare economic conditions and far-right voting at local and extralocal scales.

\section{Context and Voting in France}

France presents a case study for testing the effects of local immigration and unemployment on the vote given its history of immigration and a highly successful farright party, the Front National (which was renamed National Rally in 2018). Long a country of immigration, France became an ethnoracially diverse society in the wake of decolonialization, as migrants and their families settled primarily in the peripheries of major cities. Today, the foreign-born population and their direct descendants is estimated at about $20 \%$ of the population (Beauchemin et al. 2018). Unlike other Western societies, France does not recognize differentiations based on race/ethnicity and consequently does not collect race/ethnicity in public statistics. Despite this colorblind tradition, the integration of immigrants and their descendants has become a salient and controversial political issue. The French Republican model of integration assumes that immigrants become French by successfully incorporating French values and losing signs of ethnic distinctiveness. But the perceived cultural distance of non-European immigrants and their offspring as well as the visibility of French Muslims have led many on the political right to blame minorities for their failed integration and "unassimiability." Research has documented high levels of residential segregation among non-European immigrants and their children as well as white flight dynamics in France (Rathelot and Safi 2014; McAvay and Safi 2018; McAvay 2018).

The far-right Front National has gained traction since the 1980s by framing immigration as a scapegoat for economic hardship, increased unemployment, as well as a threat to national identity, stoking fears of insecurity and demographic invasion. The rise of the far right is further reflected in empirical evidence of anti-immigrant sentiment and ethnic prejudice in French society (Mayer et al. 2014). The party's leader, Marine Le Pen, insists heavily on the association between increased immigration and unemployment, as well as the supposed undermining of the French welfare state caused by large numbers of immigrants. The spearhead of its electoral platform in recent elections has been the "national preference" policies that aim to prioritize French over foreigners on the labor market and decrease the cost of France's welfare state by restricting access to natives only (see Mayer 2018; Shields 2013).

A few prior studies have tested how immigrant presence influences voting in France, with mixed evidence pointing to ethnic threat (Lubbers and Scheepers 2002; Mayer 2002; Della Posta 2013; Edo et al. 2019; Rojon 2013) and contact theory 
(Jolly and DiGiusto 2014; Della Posta 2013; Rojon 2013) depending on scale. No studies to our knowledge have looked at the influence of neighborhood-level characteristics on voting in France or used a multilevel approach with individual and multiple contextual scales.

\section{Hypotheses}

Building on the above, we test the following hypotheses:

H1 In line with the premises of contact theory, we anticipate that voting for the far right will decrease with higher immigrant shares at the neighborhood level only.

H2 Ethnic threat processes will be observed only at a broader spatial scale. Voting for the far right will increase in departments with higher immigrant shares.

H3 As ethnic threat processes are canceled out by regular contact, higher immigrant shares at the neighborhood level will weaken the effect of higher immigrant shares in departments.

H4 As job market opportunities largely exceed neighborhood boundaries, increased unemployment will increase voting for the far right only at the department level due to economic competition.

\section{Data and Methods}

Data come from the 2017 French Electoral Survey (Enquête electorale française) produced by the CEVIPOF. The survey is a 17 -wave panel that was conducted approximately every month between November 2015 and June 2017 on a representative sample of around 25,000 respondents. ${ }^{2}$ Our analysis focuses on wave 14 (April-May 2017) during which vote choice in the presidential election was measured $(\mathrm{N}=15,807)$. Using the geographic ID code of each respondent, we match the Electoral Survey to neighborhood and department characteristics constructed from the 2015 French census. Neighborhood ID codes were not available for $14 \%$ of respondents in wave 14. Comparison of socio-demographics and the vote choice variable for the full sample $(\mathrm{N}=15,807)$ and the sample of non-missing observations on neighborhood and all other variables used in the analysis $(\mathrm{N}=12,613)$ shows nearly identical distributions, suggesting that sample selection due to missing values does not bias the representativity of the sample. ${ }^{3}$

\footnotetext{
${ }^{2}$ See Table 3 for descriptive comparisons between the survey, the French census and prior presidential election resuts.

3 These statistics are not shown here but can be obtained upon request from the authors.
} 


\section{Vote Choice}

The dependent variable is the reported vote in the first round of the 2017 French presidential election, measured in April 2017 (Wave 14). It is coded as a dummy variable, indicating 1 if the respondent voted for the far-right candidate, Marine Le Pen (Front National) and 0 for any other candidate. Abstainers and blank ballots are not included in the analysis. We ran robustness checks to test the validity of our findings if these categories are included; results do not change.

\section{Contextual Characteristics}

The main independent variables of interest are the immigrant share and unemployment rate in voters' residential areas in 2015. These are continuous variables measured at two levels: the neighborhood (IRIS) ${ }^{4}$ and the department. ${ }^{5}$ The neighborhood (or department) immigrant share refers to the proportion of immigrants ${ }^{6}$ out of the entire neighborhood (or department) population. The unemployment rate measures the share of unemployed individuals out of the total active population of the neighborhood or department. We further control for municipality size. ${ }^{7}$

\section{Individual-Level Demographics and Attitudes}

The social and demographic characteristics of respondents as well as the attitudes they hold towards immigrants may influence both neighborhood choice and voting simultaneously. We therefore include these factors as covariates in all models. Socio-demographics include gender, age group $(<25 ; 26-35 ; 36-45 ; 46-55 ; 56-65$; $>65$ ), education (no education, professional certificate, baccalaureate, or higher education), current unemployment, and occupation (independent professions, manager, intermediary professions, white collar, blue collar, retired, student, inactive). We further include an indicator of migrant background. The French Electoral Survey includes a question on the national origin of respondents' parents and grandparents. Because African-origin immigrants and their descendants are among the

\footnotetext{
4 The neighborhood level used most commonly in French research is the IRIS (Ilôts regroupés pour l'information statistique). Defined by the census bureau, IRIS are infra-municipality units of between 1800 and 5000 inhabitants. All French municipalities of more than 10,000 inhabitants are divided into IRIS. For municipalities under 10,000 inhabitants, the municipality-level immigrant share/unemployment rate is used in lieu of the IRIS level.

5 Due to data availability, all French departments are included except for Corsica.

6 According to the definition commonly used in France, immigrants are individuals born outside of France without French citizenship at birth. The census does not count second generation immigrants.

7 Because our contextual variables of interest may also be correlated with different degrees of organizational and network power of the Front national party across geographical areas, we ran a robustness check to ensure whether our main results hold if this factor is included. We measure party power using the vote share obtained by the Front National in the 2015 regional elections, measured at the departmental level. Results are included in Table 6 in the Appendix. Our main results related to the impact of immigration are not altered by the inclusion of this covariate. The effect of department unemployment however turns insignificant.
} 
most discriminated against and segregated in French society (Safi and Simon 2013; McAvay and Safi 2018), we distinguish respondents of African origin (1) versus those with no identifiable migrant background ("the majority") or with a European or other origin $(0)$.

We also include a scale of ethnic intolerance measured in Wave 1 (November 2015). The scale is constructed from five items: "There are too many immigrants in France"; "Islam is a threat to the West"; "French natives should have priority in employment compared to foreigners"; "Immigration is a source of cultural enrichment"; and "Children of immigrants born in France are as French as anyone else." The two last items were reverse coded. Each of these items is measured with 5-point Likert scales and yield a Cronbach's alpha of 0.87 .

Table 1 presents summary statistics on all variables.

\section{Estimation Strategy}

We ran a multilevel logistic regression model predicting the far-right vote. The multilevel model is a three-level random intercept model that accounts for the nested structure of the data: individuals are clustered within neighborhoods and within departments. Given that people within the same neighborhoods or departments likely share similar observed or unobserved characteristics, using a basic logistic regression would violate the assumption of independence between observations. Intra-class correlations calculated from the base multilevel model containing no predictors show that about $8 \%$ of unexplained variance in voting can be accounted for by the neighborhood level (Table 4). Further descriptive statistics on the distribution of cases per level are reported in Table 5. Models are estimated using Stata's melogit command.

\section{Results}

Table 2 reports multilevel models predicting the likelihood of voting for Le Pen. We construct the model incrementally by first focusing on the effect of neighborhood immigration (M1a), adding other contextual-level characteristics (M1b), and including individual-level demographics (M1c). The final specification (M1d) adds the scale of ethnic intolerance. As shown in M1c, individual-level covariates reveal significant effects previously documented in the literature. In line with past research, we find that older age groups and higher education correlate negatively with voting for Le Pen, and men are more likely to support the far right compared to women (Mayer 2018). Higher status occupations (managers and intermediary professions), students, and residents of large cities are less likely to support Le Pen. The same is true for African origin minorities, but this effect is largely eliminated after controlling for ethnic intolerance in M1d. Overall, controlling for these individuallevel factors reduces the significance of the neighborhood immigrant share variable across models, indicating that some of the effect of local immigration is accounted for by sociodemographic variables that are decisive to locational outcomes and the 
Table 1 Summary statistics on all variables

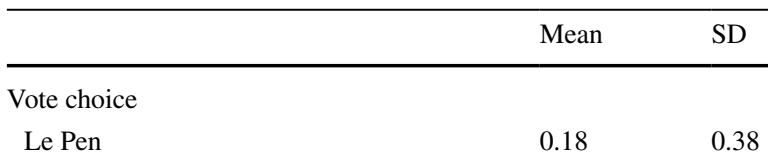

Contextual characteristics

Neighborhood immigrant share

$0.08 \quad 0.07$

Department immigrant share

$0.09 \quad 0.05$

Neighborhood unemployment rate

$0.13 \quad 0.06$

Department unemployment rate

$0.14 \quad 0.02$

Department Front National vote share

0.28

0.09

City size

$\begin{array}{lll}\text { Rural }<5000 \text { inhabitants } & 0.19 & 0.40 \\ 5000-10,000 \text { inhabitants } & 0.12 & 0.33 \\ 10,000-200,000 \text { inhabitants } & 0.26 & 0.44 \\ >200,000 & 0.43 & 0.49\end{array}$

Individual-level demographics

Migrant background

French majority or European origin $\quad 0.98 \quad 0.15$

African origin

$0.02 \quad 0.15$

Male (dummy)

$0.44 \quad 0.50$

Age

$\begin{array}{lll}<25 & 0.11 & 0.31 \\ 26-35 & 0.14 & 0.35 \\ 36-45 & 0.22 & 0.41 \\ 46-55 & 0.17 & 0.38 \\ 56-65 & 0.22 & 0.41 \\ >65 & 0.14 & 0.35\end{array}$

Education

$\begin{array}{lll}\text { No education } & 0.04 & 0.20 \\ \text { Professional certificate } & 0.23 & 0.42 \\ \text { Bac } & 0.20 & 0.40 \\ \text { University } & 0.53 & 0.50 \\ \text { Occupation } & & \\ \text { Independent professions } & 0.03 & 0.18 \\ \text { Managers } & 0.14 & 0.35 \\ \text { Intermediary professions } & 0.17 & 0.38 \\ \text { White collar } & 0.20 & 0.40 \\ \text { Blue collar } & 0.06 & 0.25 \\ \text { Retired } & 0.26 & 0.44 \\ \text { Inactive } & 0.07 & 0.25 \\ \text { Student } & 0.06 & 0.25 \\ \text { Unemployed (dummy) } & 0.04 & 0.19 \\ \text { Intolerance scale } & 3.16 & 1.02 \\ \text { N } & 12,613 & \end{array}$

Source: The French Electoral Survey, Wave 14 (2017) 
Table 2 Multilevel model predicting the Le Pen vote

\begin{tabular}{|c|c|c|c|c|}
\hline & M1a & M1b & M1c & M1d \\
\hline \multicolumn{5}{|l|}{ Neighborhood level } \\
\hline Immigrant share & $\begin{array}{l}-1.503^{* * *} \\
(0.418)\end{array}$ & $\begin{array}{l}-2.189 \text { *** } \\
(0.517)\end{array}$ & $\begin{array}{l}-1.160 * \\
(0.528)\end{array}$ & $\begin{array}{l}-1.229 * \\
(0.624)\end{array}$ \\
\hline Unemployment rate & & $\begin{array}{l}1.027 * \\
(0.472)\end{array}$ & $\begin{array}{l}0.387 \\
(0.483)\end{array}$ & $\begin{array}{l}0.740 \\
(0.581)\end{array}$ \\
\hline \multicolumn{5}{|l|}{ Department level } \\
\hline Immigrant share & & $\begin{array}{l}0.955 \\
(0.877)\end{array}$ & $\begin{array}{l}2.564 * * \\
(0.890)\end{array}$ & $\begin{array}{l}2.439 * * \\
(0.919)\end{array}$ \\
\hline Unemployment rate & & $\begin{array}{l}8.794 * * * \\
(1.803)\end{array}$ & $\begin{array}{l}8.771 * * * \\
(1.755)\end{array}$ & $\begin{array}{l}7.252 * * * \\
(1.765)\end{array}$ \\
\hline \multicolumn{5}{|l|}{ Individual level } \\
\hline Female & & & $\begin{array}{l}-0.251 * * * \\
(0.053)\end{array}$ & $\begin{array}{l}-0.169 * * \\
(0.064)\end{array}$ \\
\hline \multicolumn{5}{|l|}{ Age group/ref: $<25$} \\
\hline $26-35$ & & & $\begin{array}{l}-0.176 \\
(0.120)\end{array}$ & $\begin{array}{l}-0.057 \\
(0.147)\end{array}$ \\
\hline $36-45$ & & & $\begin{array}{l}-0.280^{*} \\
(0.114)\end{array}$ & $\begin{array}{l}-0.112 \\
(0.140)\end{array}$ \\
\hline $46-55$ & & & $\begin{array}{l}-0.502^{* * *} \\
(0.118)\end{array}$ & $\begin{array}{l}-0.530 * * * \\
(0.145)\end{array}$ \\
\hline $56-65$ & & & $\begin{array}{l}-0.817 * * * \\
(0.129)\end{array}$ & $\begin{array}{l}-0.885^{* * *} \\
(0.158)\end{array}$ \\
\hline$>65$ & & & $\begin{array}{l}-1.243^{* * *} \\
(0.160)\end{array}$ & $\begin{array}{l}-1.448^{* * *} \\
(0.193)\end{array}$ \\
\hline \multicolumn{5}{|l|}{ Education/ref: no education } \\
\hline Professional certificate & & & $\begin{array}{l}-0.322^{* *} \\
(0.109)\end{array}$ & $\begin{array}{l}-0.307 * \\
(0.131)\end{array}$ \\
\hline High school diploma & & & $\begin{array}{l}-0.631 * * * \\
(0.114)\end{array}$ & $\begin{array}{l}-0.565^{* * *} \\
(0.137)\end{array}$ \\
\hline University & & & $\begin{array}{l}-1.263^{* * *} \\
(0.116)\end{array}$ & $\begin{array}{l}-0.981^{* * *} \\
(0.138)\end{array}$ \\
\hline Unemployed (dummy) & & & $\begin{array}{l}0.239 * \\
(0.117)\end{array}$ & $\begin{array}{l}0.300 * \\
(0.144)\end{array}$ \\
\hline \multicolumn{5}{|l|}{ Occcupation/ref: White collar } \\
\hline Independent & & & $\begin{array}{l}-0.103 \\
(0.135)\end{array}$ & $\begin{array}{l}-0.155 \\
(0.163)\end{array}$ \\
\hline Managers & & & $\begin{array}{l}-0.774 * * * \\
(0.104)\end{array}$ & $\begin{array}{l}-0.668^{* * *} \\
(0.124)\end{array}$ \\
\hline Intermediary professions & & & $\begin{array}{l}-0.503^{* * *} \\
(0.086)\end{array}$ & $\begin{array}{l}-0.316^{* *} \\
(0.102)\end{array}$ \\
\hline Blue collar & & & $\begin{array}{l}0.014 \\
(0.100)\end{array}$ & $\begin{array}{l}0.063 \\
(0.121)\end{array}$ \\
\hline
\end{tabular}


Table 2 (continued)

\begin{tabular}{|c|c|c|c|c|}
\hline & M1a & M1b & M1c & M1d \\
\hline Retired & & & $\begin{array}{l}-0.168 \\
(0.110)\end{array}$ & $\begin{array}{l}-0.185 \\
(0.130)\end{array}$ \\
\hline Not working & & & $\begin{array}{l}0.161 \\
(0.099)\end{array}$ & $\begin{array}{l}0.058 \\
(0.121)\end{array}$ \\
\hline Student & & & $\begin{array}{l}-0.936^{* * *} \\
(0.152)\end{array}$ & $\begin{array}{l}-0.703 * * * \\
(0.189)\end{array}$ \\
\hline \multicolumn{5}{|c|}{$\begin{array}{l}\text { Migrant background/ref: majority or } \\
\text { European origin }\end{array}$} \\
\hline African origin & & & $\begin{array}{l}-1.453 * * * \\
(0.253)\end{array}$ & $\begin{array}{l}-0.402 \\
(0.291)\end{array}$ \\
\hline \multicolumn{5}{|c|}{ City size/ref: $<5000$ inhabitants } \\
\hline $5000-10,000$ & & & $\begin{array}{l}0.040 \\
(0.086)\end{array}$ & $\begin{array}{l}0.071 \\
(0.104)\end{array}$ \\
\hline $10,000-200,000$ & & & $\begin{array}{l}-0.088 \\
(0.075)\end{array}$ & $\begin{array}{l}-0.057 \\
(0.090)\end{array}$ \\
\hline$>200,000$ & & & $\begin{array}{l}-0.251 * * \\
(0.082)\end{array}$ & $\begin{array}{l}-0.195^{*} \\
(0.096)\end{array}$ \\
\hline Intolerance scale & & & & $\begin{array}{l}1.669 * * * \\
(0.064)\end{array}$ \\
\hline Constant & $\begin{array}{l}-1.476^{* * * *} \\
(0.068)\end{array}$ & $\begin{array}{l}-2.833^{* * * *} \\
(0.257)\end{array}$ & $\begin{array}{l}-1.134 * * * \\
(0.288)\end{array}$ & $\begin{array}{l}-7.333 * * * \\
(0.408)\end{array}$ \\
\hline $\mathrm{N}$ & 12,613 & 12,613 & 12,490 & 12,371 \\
\hline Model fit: AIC & $11,670.16$ & $11,644.34$ & $10,867.52$ & 8324.548 \\
\hline$\left(\right.$ LR test-Chi ${ }^{2}$ ) & $98.07 * * *$ & $52.41 * * *$ & $34.18 * * *$ & $14.64 * *$ \\
\hline
\end{tabular}

Source: The French Electoral Survey, Wave 14 (2017). Standard errors in parentheses

$* * * \mathrm{p}<0.001, * * \mathrm{p}<0.01, * \mathrm{p}<0.05$

vote. Further, as M1d shows, higher levels of intolerance towards immigrants and minorities is, unsurprisingly, positively associated with casting a vote for Le Pen. Yet again, accounting for levels of ethnic intolerance does not entirely absorb the effect of the neighborhood immigrant share. Hence, the impact of context displayed in these models cannot be explained solely by residential sorting, namely by the fact that respondents with certain sociodemographic or attitudinal profiles choose to live in immigrant areas. ${ }^{8}$

\footnotetext{
${ }^{8}$ We estimate a final model that included all variables in Model 1c, with the addition of an interaction term between neighborhood immigrant share and migrant background. The full model is presented in Table 8 in the Appendix. The slope for the neighborhood immigrant share is negative and significant for the majority and European origin voters. This test provides further evidence of contact by illustrating that the negative association between local immigration and the far-right vote is not driven by minorities living in these neighborhoods.
} 

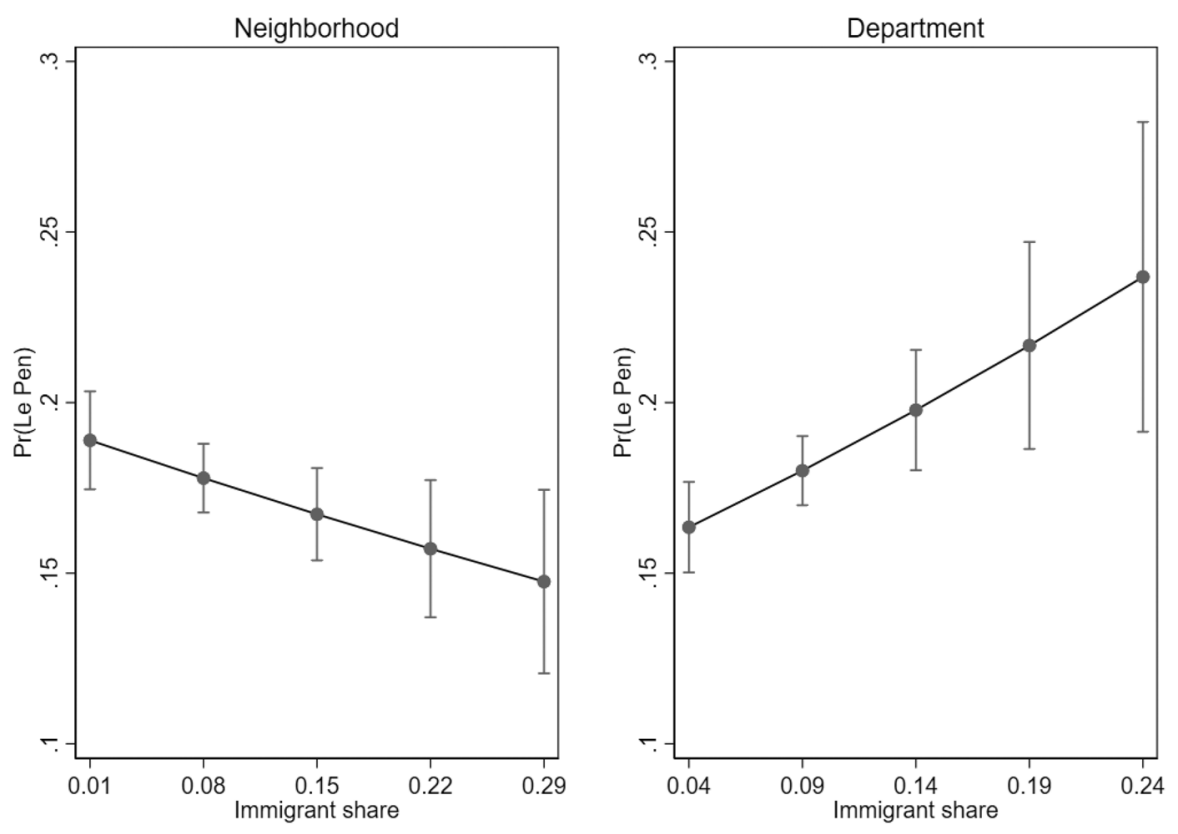

Fig. 1 Predicted probabilities of voting for the far right by levels of immigration. Source: The French Electoral Survey, Wave 14 (2017)

The contextual effects relating to our main hypotheses are explored using predicted probability graphs computed from the main model (M1c). Figure 1 shows the probability of voting for the far right by the neighborhood immigrant share (left panel) and the department immigrant share (right panel). The x-axis plots the mean, one standard deviation below the mean as well as three standard deviations above the mean of the immigrant share variables. The results indicate contrasting patterns according to scale. In line with the contact hypothesis $\left(\mathrm{H}_{1}\right)$, voters in immigrantdense neighborhoods are less likely to cast a vote for the far right compared to people living in local areas with lower shares of immigrants. Net of other factors, the average predicted probability of voting for Le Pen drops by nearly $5 \%$ points among residents of neighborhoods with $1 \%$ of immigrants compared to those living in areas with $29 \%$ of immigrants.

However, department-level immigration exerts an opposite and stronger effect on the likelihood of supporting the far right. In this case, a positive correlation is observed between high immigration and far-right voting, suggesting ethnic threat $\left(\mathrm{H}_{2}\right)$. The predicted likelihood of voting for Le Pen increases on average by about $8 \%$ points between voters in departments with low shares of immigrants (4\%) and those with high levels of immigration (24\%). These findings are in line with the halo effect literature that posits that the far-right vote increases in places that are close to immigrant-dense areas rather than in immigrant-dense areas themselves.

Figure 2 illustrates the association between unemployment rates and the probability of voting for the far right, again at both the neighborhood (left panel) and 

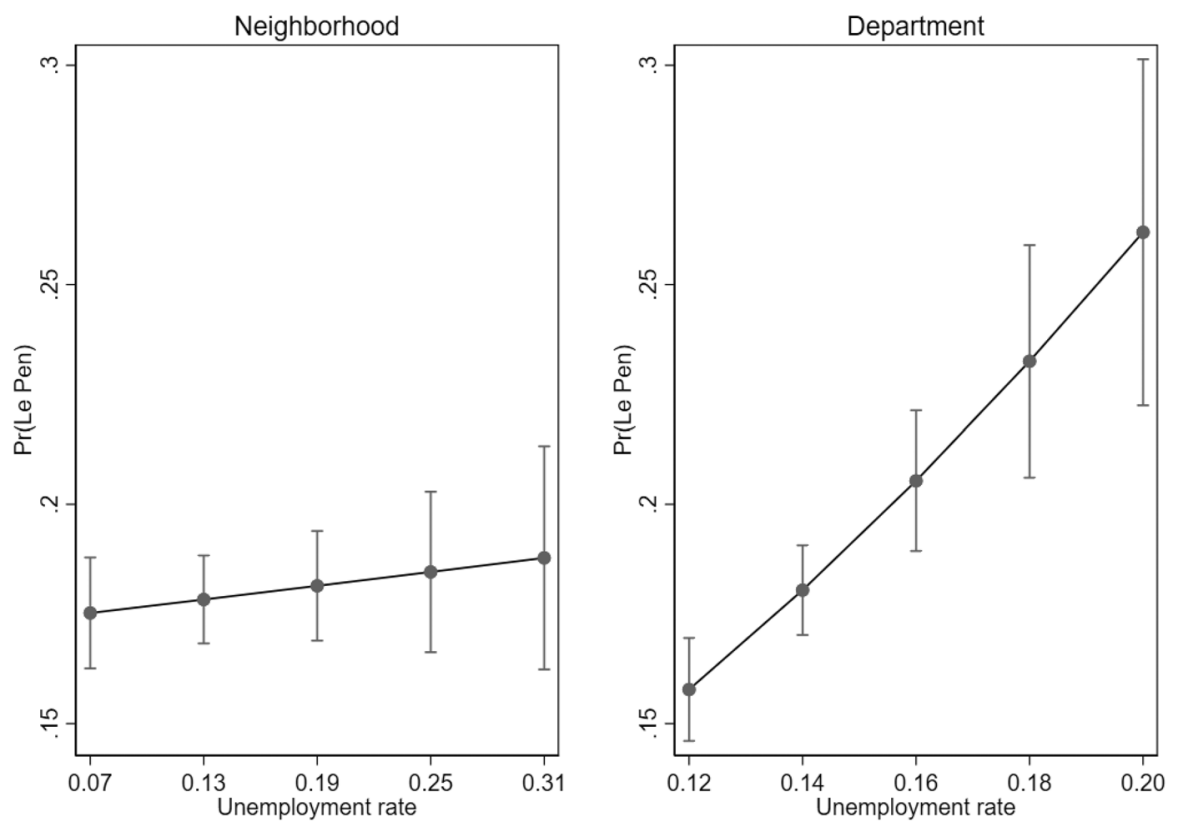

Fig. 2 Predicted probabilities of voting for the far right by levels of unemployment. Source: The French Electoral Survey, Wave 14 (2017)

department (right panel) levels. Controlling for other factors, we find no significant effect of the neighborhood unemployment rate. Voters living in disadvantaged local areas (31\% unemployment) have about equal chances of voting for Le Pen than those from less deprived spaces (7\% unemployment). Yet, again the findings indicate a different pattern at the broader level of the department. Voters from departments hit hard by unemployment have on average about a $25 \%$ chance of voting for Le Pen, while the probability is only $16 \%$ for voters in low-unemployment areas $\left(\mathrm{H}_{4}\right)$. The department unemployment rate produces the greatest variation in the probability of voting for Le Pen compared to all other contextual variables.

Up until now the results suggest a negative association between immigration at the neighborhood level and voting for the far right and a positive association between immigration and unemployment at the department level and voting for this party. Given that direct contact with immigrants reduces voters' chances of supporting the far right, we further expect that department level ethnic threat processes will be canceled out by regular contact. We test this hypothesis by introducing an interaction between neighborhood and department level immigrant shares (full model results are included in Table 7 in the Appendix).

Figure 3 illustrates the results from this interaction. The change in probability in voting for Le Pen associated with an increase in department level immigration is positive and significant for voters living in most neighborhoods. However, in neighborhoods with an above-average level of immigration, the positive effect of the department on far-right voting is no longer found. This finding suggests that 


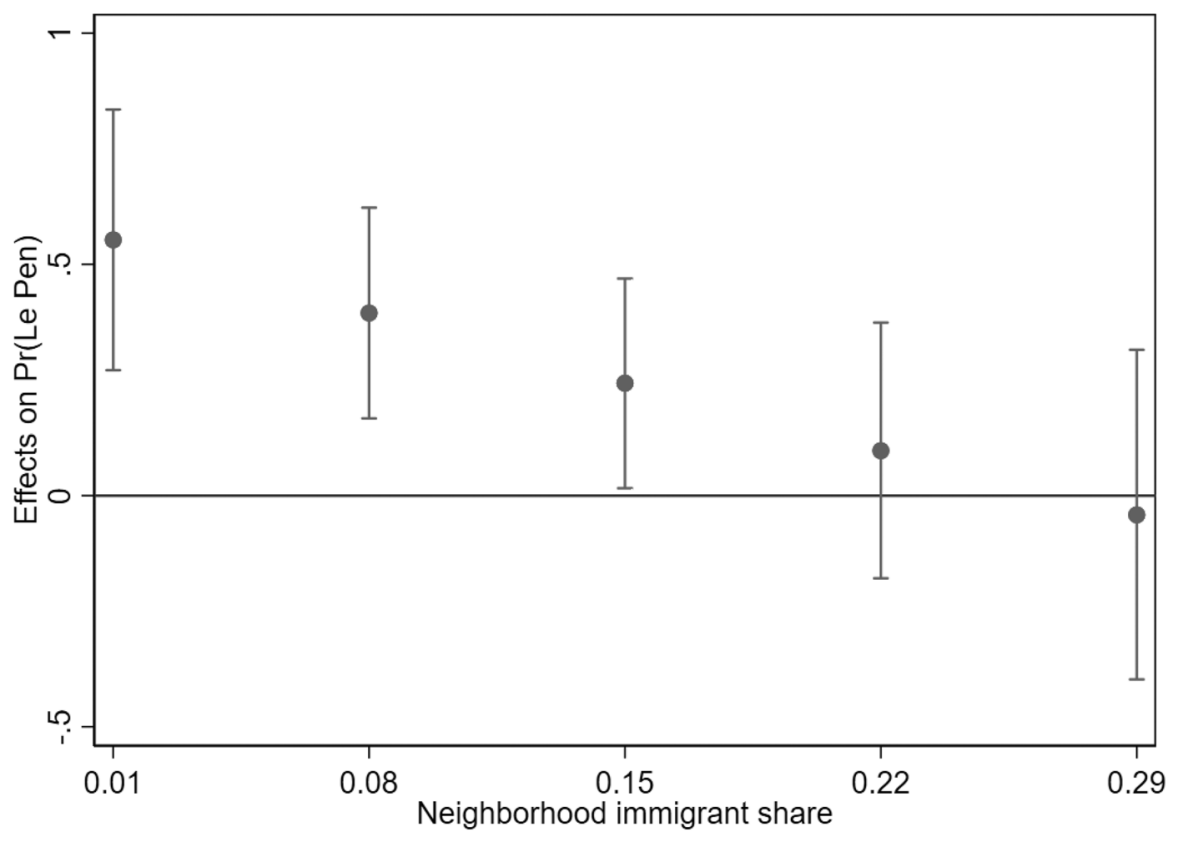

Fig. 3 Marginal effect of the department immigrant share by neighborhood immigration Source: The French Electoral Survey, Wave 14 (2017)

adherence to radical right parties is triggered specifically among voters who have no frequent direct contacts with immigrants but are sensitive to their presence in surrounding areas. On the other hand, the department level effect of immigration is not salient among voters who have direct contact with immigrants, i.e. when neighborhood immigration is high. Contact therefore eliminates the association between immigration and far-right voting that is visible at the level of the department $\left(\mathrm{H}_{3}\right)$.

\section{Discussion and Conclusion}

The consequences of immigration and economic hardship for the changing political landscape of contemporary democracies are widely discussed both in and outside of the social sciences. While many studies exist on this topic, the extant literature has come up with contrasting conclusions about the impact of contextual variables on voting behavior. Drawing on the economic competition, contact theory and ethnic threat perspectives, this article examined the role of immigration and unemployment in voters' residential environments using the case of the 2017 French presidential election. Using survey data matched with the census, we simultaneously accounted for the effects of these variables at two spatial scales, the neighborhood and the department, in a multilevel model. We find that voters in neighborhoods with high levels of immigration were less likely to vote for the far right, in line with contact theory. However, contrasting patterns emerged at the department level, where 
increased immigration correlated with higher support for Le Pen. Yet residents of neighborhoods with high share of immigrants still had reduced chances of voting for Le Pen, even when they came from ethnically diverse departments.

These findings bear important implications for the empirical assessment of economic competition, contact theory and ethnic threat. First, models should combine individual and contextual level data and account for multiple spatial scales at once. Second, while most prior studies have assessed contact theory by drawing on broad residential environments, levels of immigration need to be captured within neighborhoods where interactions are most likely to occur. Our results point to the conclusion that ethnic threat and contact theory are not mutually exclusive patterns, but rather simultaneous processes that operate at different spatial scales. This finding joins prior studies from France using aggregate-level data (Della Posta 2013; Rojon 2013) and resonates with research indicating the existence of halo effects on far-right voting (Rydgren and Ruth 2013). Voters who live in low-diversity local environments but feel "surrounded" by immigrants in the broader area seem to be more susceptible to the platforms of far-right parties.

This study nonetheless suffers from methodological limitations, which provide avenues for further research. While we have accounted for individual characteristics such as socio-demographics and ethnic intolerance that may influence residential sorting, due to the cross-sectional nature of the data, the patterns relating to local immigration and unemployment shown here cannot be interpreted as fully causal effects given the endogeneity of locational choice and the vote. Residential mobility patterns also intervene in the interpretation of our findings. In particular, given evidence of white flight in France (Rathelot and Safi 2014; McAvay 2018), voters who harbor negative attitudes towards immigrants may move out of immigrant dense neighborhoods. This would contribute to a form of geographical polarization whereby more ethnically tolerant voters live (and remain) in immigrant areas while more intolerant voters choose to settle in spaces with fewer immigrants. Our data do not include information on neighborhood-level residential mobility that would allow us to account for such processes. We are thus not fully able to identify whether the evidence of contact theory found here reflects a pure contextual effect or residential sorting. Future research could use longitudinal data in order to investigate whether residential mobility over time leads to individual changes in voting behavior (Gallego et al. 2016). A panel design would also enable the salience-of-change hypothesis to be investigated (Newman and Velez 2014). Our finding that the likelihood of voting for the far right is lower in immigrant neighborhoods does not exclude the possibility that areas experiencing rapid increases in immigration will change citizens' voting behavior. Future research could determine whether changes in the local immigrant composition over time predict individual-level increases in far-right voting, while accounting for residential mobility patterns such as white flight.

Future research could also seek to identify additional conditions under which economic competition, ethnic threat and contact might operate. For instance, studies could investigate whether living in disadvantaged areas shapes perceptions of economic competition or threat differently across occupational groups or personality types. Moreover, research could explore how economic competition and ethnic threat interact at various spatial scales. Further, quantitative and 
qualitative work is necessary to more directly uncover the psychological apparatus of contact. For instance, what role does the type and frequency of contact between natives and immigrants (e.g. in the neighborhood, at the workplace, in schools or in the public space-see for instance Enos 2017) play in the development of tolerance (or ethnic animus)? This would advance our understanding of the precise conditions under which contact transforms attitudes and would offer a more direct test of contact theory.

Finally, with some rare exceptions (Edo et al. 2019), extant research on contextual effects has solely focused on the far right. Further extensions of this research could use combined individual and contextual level data to explore how neighborhood immigration or unemployment have electoral consequences that extend to the full range of the political spectrum.

\section{Appendix}

See Tables 3, 4, 5, 6, 7 and 8 . 


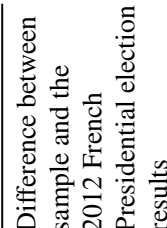

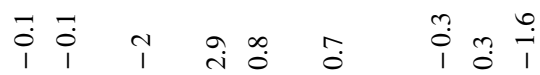

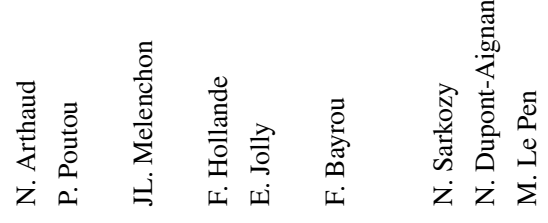

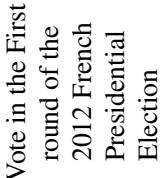

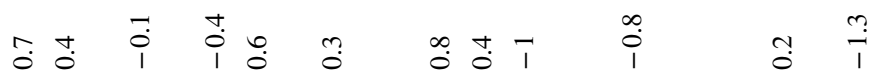

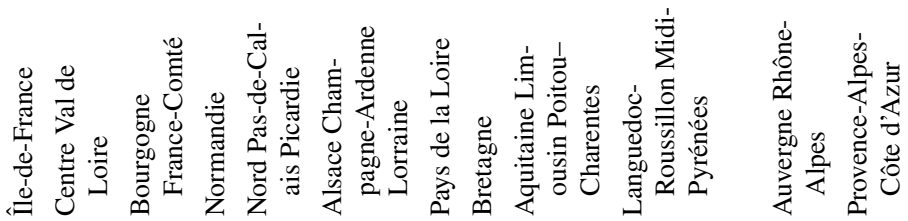

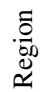

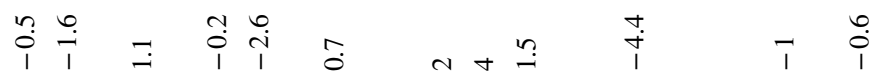

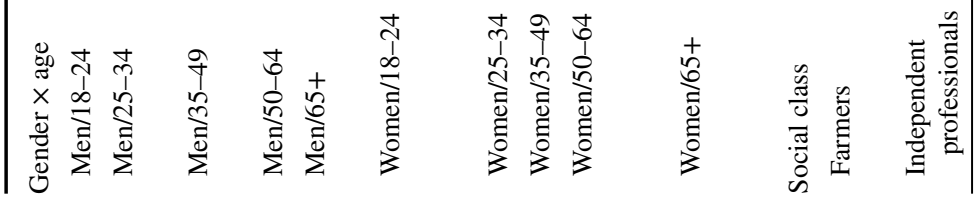




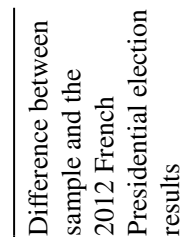

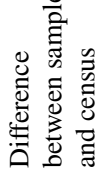

$\overrightarrow{\frac{1}{2}} \stackrel{\frac{1}{2}}{-}$

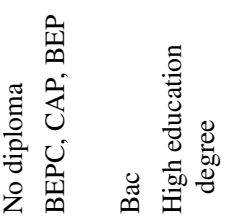

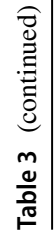

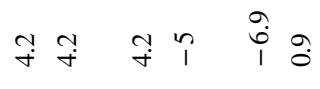

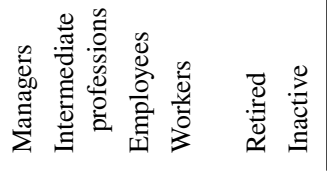


Table 4 Intra-class correlations for the empty multilevel model

Table 5 Number of cases within neighborhood and department levels in multilevel analysis (M1c)

\begin{tabular}{llll}
\hline Level & ICC & SE & $95 \%$ CI \\
\hline Department & 0.032 & 0.007 & {$[0.020-0.050]$} \\
Neighborhood & 0.082 & 0.039 & {$[0.032-0.197]$}
\end{tabular}

Source: The French Electoral Survey, Wave 14 (2017)

\begin{tabular}{lcrrr}
\hline Level & Number of groups & Mean & Min & Max \\
\hline Department & 94 & 132.9 & 12 & 603 \\
Neighborhood & 10,095 & 1.2 & 1 & 8 \\
\hline
\end{tabular}

Source: The French Electoral Survey, Wave 14 (2017) 
Table 6 Multilevel model predicting the Le Pen Vote (controlling for department-level Front National vote share)

\begin{tabular}{|c|c|}
\hline & Vote for Le Pen \\
\hline \multicolumn{2}{|l|}{ Neighborhood level } \\
\hline Immigrant share & $\begin{array}{l}-1.206^{*} \\
(0.525)\end{array}$ \\
\hline Unemployment rate & $\begin{array}{l}0.329 \\
(0.480)\end{array}$ \\
\hline \multicolumn{2}{|l|}{ Department level } \\
\hline Immigrant share & $\begin{array}{l}3.827 * * * \\
(0.679)\end{array}$ \\
\hline Unemployment rate & $\begin{array}{l}-0.573 \\
(1.502)\end{array}$ \\
\hline FN vote share & $\begin{array}{l}3.553 * * * \\
(0.398)\end{array}$ \\
\hline \multicolumn{2}{|l|}{ Individual level } \\
\hline Female & $\begin{array}{l}-0.245^{* * *} \\
(0.053)\end{array}$ \\
\hline \multicolumn{2}{|l|}{ Age group/ref: $<25$} \\
\hline $26-35$ & $\begin{array}{l}-0.181 \\
(0.120)\end{array}$ \\
\hline $36-45$ & $\begin{array}{l}-0.278^{*} \\
(0.114)\end{array}$ \\
\hline $46-55$ & $\begin{array}{l}-0.501 * * * \\
(0.117)\end{array}$ \\
\hline $56-65$ & $\begin{array}{l}-0.816^{* * * *} \\
(0.129)\end{array}$ \\
\hline$>65$ & $\begin{array}{l}-1.241 * * * \\
(0.160)\end{array}$ \\
\hline \multicolumn{2}{|l|}{ Education/ref: no education } \\
\hline Professional certificate & $\begin{array}{l}-0.326^{* * *} \\
(0.109)\end{array}$ \\
\hline High school diploma & $\begin{array}{l}-0.622 * * * \\
(0.114)\end{array}$ \\
\hline University & $\begin{array}{l}-1.257 * * * \\
(0.116)\end{array}$ \\
\hline Unemployed (dummy) & $\begin{array}{l}0.229 * \\
(0.117)\end{array}$ \\
\hline \multicolumn{2}{|l|}{ Occcupation/ref: White collar } \\
\hline Independent & $\begin{array}{l}-0.105 \\
(0.135)\end{array}$ \\
\hline Managers & $\begin{array}{l}-0.770 * * * \\
(0.104)\end{array}$ \\
\hline Intermediary professions & $\begin{array}{l}-0.501 * * * \\
(0.085)\end{array}$ \\
\hline Blue collar & 0.026 \\
\hline
\end{tabular}


Table 6 (continued)

Vote for Le Pen

Retired

(0.099)

$-0.165$

(0.110)

Not working

0.164

(0.098)

Student

$-0.937 * * *$

(0.152)

Migrant background/ref: majority or European origin

African origin

$-1.437 * * *$

$(0.253)$

City size/ref: $<5000$ inhabitants

\begin{tabular}{ll}
$5000-10,000$ & 0.041 \\
$10,000-200,000$ & $(0.085)$ \\
& -0.078 \\
$>200,000$ & $(0.074)$ \\
& $-0.210^{* * *}$ \\
Constant & $(0.076)$ \\
& $-0.992 * * *$ \\
N & $(0.223)$ \\
Model fit: AIC & 12,490 \\
(LR test-Chi $^{2}$ ) & $10,817.58$ \\
\hline
\end{tabular}

Source: The French Electoral Survey, Wave 14 (2017). Standard errors in parentheses

$* * * \mathrm{p}<0.001, * * \mathrm{p}<0.01,{ }^{*} \mathrm{p}<0.05$ 
Table 7 Multilevel model predicting the Le Pen Vote including an interaction between department and neighborhood immigration

\begin{tabular}{|c|c|}
\hline & Vote for Le Pen \\
\hline \multicolumn{2}{|l|}{ Neighborhood level } \\
\hline Neighborhood immigrant share & $\begin{array}{l}0.758 \\
(0.909)\end{array}$ \\
\hline Neighborhood unemployment rate & $\begin{array}{l}0.203 \\
(0.485)\end{array}$ \\
\hline \multicolumn{2}{|l|}{ Department level } \\
\hline Department immigrant share & $\begin{array}{l}4.126 * * * \\
(1.043)\end{array}$ \\
\hline Department unemployment rate & $\begin{array}{l}9.144 * * * \\
(1.664)\end{array}$ \\
\hline \multicolumn{2}{|l|}{ Interaction } \\
\hline $\begin{array}{l}\text { Neighborhood immigrant share } \times \text { department } \\
\text { immigrant share }\end{array}$ & $\begin{array}{l}-15.352 * \\
(6.067)\end{array}$ \\
\hline \multicolumn{2}{|l|}{ Individual level } \\
\hline Female & $\begin{array}{l}-0.249 * * * \\
(0.053)\end{array}$ \\
\hline \multicolumn{2}{|l|}{ Age group/ref: $<25$} \\
\hline $26-35$ & $\begin{array}{l}-0.173 \\
(0.120)\end{array}$ \\
\hline $36-45$ & $\begin{array}{l}-0.275^{*} \\
(0.114)\end{array}$ \\
\hline $46-55$ & $\begin{array}{l}-0.502 * * * \\
(0.117)\end{array}$ \\
\hline $56-65$ & $\begin{array}{l}-0.815^{* * * *} \\
(0.129)\end{array}$ \\
\hline$>65$ & $\begin{array}{l}-1.240 * * * \\
(0.160)\end{array}$ \\
\hline \multicolumn{2}{|l|}{ Education/ref: no education } \\
\hline Professional certificate & $\begin{array}{l}-0.322^{* *} \\
(0.109)\end{array}$ \\
\hline High school diploma & $\begin{array}{l}-0.629 * * * \\
(0.114)\end{array}$ \\
\hline University & $\begin{array}{l}-1.264 * * * \\
(0.116)\end{array}$ \\
\hline Unemployed (dummy) & $\begin{array}{l}0.235^{*} \\
(0.117)\end{array}$ \\
\hline \multicolumn{2}{|l|}{ Occcupation/ref: White collar } \\
\hline Independent & $\begin{array}{l}-0.102 \\
(0.135)\end{array}$ \\
\hline Managers & $\begin{array}{l}-0.773 * * * \\
(0.104)\end{array}$ \\
\hline Intermediary professions & $-0.503 * * *$ \\
\hline
\end{tabular}


Table 7 (continued)

Vote for Le Pen

\begin{tabular}{|c|c|}
\hline & $(0.086)$ \\
\hline \multirow[t]{2}{*}{ Blue collar } & 0.016 \\
\hline & $(0.100)$ \\
\hline \multirow[t]{2}{*}{ Retired } & -0.167 \\
\hline & $(0.110)$ \\
\hline \multirow[t]{2}{*}{ Not working } & 0.159 \\
\hline & $(0.098)$ \\
\hline \multirow[t]{2}{*}{ Student } & $-0.932 * * *$ \\
\hline & $(0.152)$ \\
\hline \multicolumn{2}{|c|}{$\begin{array}{l}\text { Migrant background/ref: majority or European } \\
\text { origin }\end{array}$} \\
\hline \multirow[t]{2}{*}{ African origin } & $-1.443^{* * *}$ \\
\hline & $(0.253)$ \\
\hline \multicolumn{2}{|c|}{ City size/ref: $<5000$ inhabitants } \\
\hline \multirow[t]{2}{*}{$5000-10,000$} & 0.034 \\
\hline & $(0.086)$ \\
\hline \multirow[t]{2}{*}{$10,000-200,000$} & -0.106 \\
\hline & $(0.075)$ \\
\hline \multirow[t]{2}{*}{$>200,000$} & $-0.273^{* * *}$ \\
\hline & $(0.082)$ \\
\hline \multirow[t]{2}{*}{ Constant } & $-1.294 * * *$ \\
\hline & $(0.284)$ \\
\hline $\mathrm{N}$ & 12,490 \\
\hline Model fit: AIC & $10,863.1$ \\
\hline$\left(\right.$ LR test-Chi $\left.{ }^{2}\right)$ & $21.98 * * *$ \\
\hline
\end{tabular}

Source: The French Electoral Survey, Wave 14 (2017). Standard errors in parentheses

$* * * \mathrm{p}<0.001, * * \mathrm{p}<0.01, * \mathrm{p}<0.05$ 
Table 8 Multilevel model predicting the Le Pen vote including an interaction between neighborhood immigration and migrant background

Vote for Le Pen

\section{Interaction}

Effect of African origin

$-1.502 * * *$

(0.406)

Neighborhood immigrant share x majority/European

$-1.168 *$

(0.531)

Neighborhood immigrant share $\mathrm{x}$ African origin

Neighborhood level

Neighborhood unemployment rate

Department level

Department unemployment rate

$8.771 * * *$

(1.755)

Department immigrant share

Individual level

Female

$-0.251 * * *$

(0.053)

Age group/ref: $<25$

26-35

$-0.176$

(0.120)

36-45

$-0.281^{*}$

(0.114)

46-55

$-0.502 * * *$

(0.118)

$56-65$

$-0.817 * * *$

(0.129)

$>65$

$-1.243 * * *$

(0.160)

Education/ref: no education

Professional certificate

$-0.321 * *$

(0.109)

High school diploma

$-0.630 * * *$

(0.114)

University

$-1.263 * * *$

(0.116)

Unemployed (dummy)

$0.239 *$

(0.117)

Occcupation/ref: White collar

Independent

(0.135) 
Table 8 (continued)

Vote for Le Pen

Managers

$-0.774 * * *$

Intermediary professions

Blue collar

Retired

Not working

Student

City size/ref: $<5000$ inhabitants

5000-10,000

$10,000-200,000$

$>200,000$

Constant

$\mathrm{N}$

(LR test-Chi ${ }^{2}$ )

Model fit: AIC

$10,869.5$

Source: The French Electoral Survey, Wave 14 (2017). Standard errors in parentheses $* * * \mathrm{p}<0.001, * * \mathrm{p}<0.01, * \mathrm{p}<0.05$

Acknowledgements The authors would like to thank Mike Medeiros, Ognjen Obućina, Sofia Vasilopoulou, the participants of the seminar in Comparative Politics of the University of York, the three anonymous reviewers and the editor for their valuable comments and suggestions. We are also very grateful for the financial support provided by the INEQ AT WORK project (French state grant ANR-17-CE41-0009), which allowed us to access French census data via the Centre d'accès sécurisé aux données (CASD).

Open Access This article is licensed under a Creative Commons Attribution 4.0 International License, which permits use, sharing, adaptation, distribution and reproduction in any medium or format, as long as you give appropriate credit to the original author(s) and the source, provide a link to the Creative Commons licence, and indicate if changes were made. The images or other third party material in this article are included in the article's Creative Commons licence, unless indicated otherwise in a credit line to the material. If material is not included in the article's Creative Commons licence and your intended use is not permitted by statutory regulation or exceeds the permitted use, you will need to obtain permission directly from the copyright holder. To view a copy of this licence, visit http://creativecommons.org/licen ses/by/4.0/. 


\section{References}

Allport, G. W. (1954). The nature of prejudice. Reading, MA: Addison-Wesley.

Amengay, A., \& Stockemer, D. (2018). The radical right in Western Europe: A meta-analysis of structural factors. Political Studies Review, 17, 30-40.

Anderson, C. J. (1996). Economics, politics, and foreigners: Populist party support in Denmark and Norway. Electoral Studies, 15(4), 497-511.

Arzheimer, K. (2009). Contextual factors and the extreme right vote in Western Europe, 1980-2002. American Journal of Political Science, 53(2), 259-275.

Arzheimer, K., \& Carter, E. (2006). Political opportunity structures and right-wing extremist party success. European Journal of Political Research, 45(3), 419-443.

Beauchemin, C., Hamel, C., \& Simon, P. (2018). Trajectories and origins: Survey on the diversity of the French population (Vol. 8). Cham: Springer.

Coffé, H., Heyndels, B., \& Vermeir, J. (2007). Fertile grounds for extreme right-wing parties: Explaining the Vlaams Blok's electoral success. Electoral Studies, 26(1), 142-155.

Della Posta, D. J. (2013). Competitive threat, intergroup contact, or both? Immigration and the dynamics of Front National voting in France. Social forces, 92(1), 249-273.

Dinas, E., \& van Spanje, J. (2011). Crime story: The role of crime and immigration in the anti-immigration vote. Electoral Studies, 30(4), 658-671.

Edo, A., Giesing, Y., Öztunc, J., \& Poutvaara, P. (2019). Immigration and electoral support for the far-left and the far-right. European Economic Review, 115, 99-143.

Enos, R. D. (2017). The space between us: Social geography and politics. Cambridge: Cambridge University Press.

Gallego, A., Buscha, F., Sturgis, P., \& Oberski, D. (2016). Places and preferences: A longitudinal analysis of self-selection and contextual effects. British Journal of Political Science, 46(3), 529-550.

Georgiadou, V., Rori, L., \& Roumanias, C. (2018). Mapping the European far right in the 21st century: A meso-level analysis. Electoral Studies, 54, 103-115.

Golder, M. (2003). Explaining variation in the success of extreme right parties in Western Europe. Comparative Political Studies, 36(4), 432-466.

Green, E. G., Sarrasin, O., Baur, R., \& Fasel, N. (2016). From stigmatized immigrants to radical right voting: A multilevel study on the role of threat and contact. Political Psychology, 37(4), 465-480.

Halla, M., Wagner, A. F., \& Zweimüller, J. (2017). Immigration and voting for the far right. Journal of the European Economic Association, 15(6), 1341-1385.

Hangartner, D., Dinas, E., Marbach, M., Matakos, K., \& Xefteris, D. (2019). Does exposure to the refugee crisis make natives more hostile? American Political Science Review, 113(2), 442-455.

Jackman, R. W., \& Volpert, K. (1996). Conditions favouring parties of the extreme right in Western Europe. British Journal of Political Science, 26(4), 501-521.

Jolly, S. K., \& DiGiusto, G. M. (2014). Xenophobia and immigrant contact: French public attitudes toward immigration. The Social Science Journal, 51(3), 464-473.

Kaufmann, E., \& Harris, G. (2015). "White Flight" or positive contact? Local diversity and attitudes to immigration in Britain. Comparative Political Studies, 48(12), 1563-1590.

Knigge, P. (1998). The ecological correlates of right-wing extremism in Western Europe. European Journal of Political Research, 34(2), 249-279.

Lubbers, M., \& Scheepers, P. (2000). Individual and contextual characteristics of the German extreme right-wing vote in the 1990s. A test of complementary theories. European Journal of Political Research, 38(1), 63-94.

Lubbers, M., \& Scheepers, P. (2002). French front national voting: A micro and macro perspective. Ethnic and Racial Studies, 25(1), 120-149.

Lubbers, M., Gijsberts, M., \& Scheepers, P. (2002). Extreme right-wing voting in Western Europe. European Journal of Political Research, 41(3), 345-378.

Lucassen, G., \& Lubbers, M. (2012). Who fears what? Explaining far-right-wing preference in Europe by distinguishing perceived cultural and economic ethnic threats. Comparative Political Studies, 45(5), 547-574.

Maxwell, R. (2019). Cosmopolitan immigration attitudes in large European cities: Contextual or compositional effects? American Political Science Review, 113(2), 456-474.

Mayer, N. (2002). Ces Français qui votent FN. Paris: Flammarion. 
Mayer, N. (2018). The radical right in France. In J. Rydgren (Ed.), The oxford handbook of the radical right (pp. 433-451). Oxford: Oxford University Press.

Mayer, N., Michelat, G., Tiberj, V., \& Vitale, T. (2014). The perspective of researchers: A growing refusal of the other. In Commisision nationale consultative des droits de l'homme (Ed.), La lutte contre le racisme, l'antisémitisme et la xénophobie. Année 2013 (pp. 157-208). Paris: La Documentation française.

McAvay, H. (2018). The ethnoracial context of residential mobility in France: Neighbourhood out-migration and relocation. Population, Space and Place, 24(6), e2138.

McAvay, H., \& Safi, M. (2018). Is there really such thing as immigrant spatial assimilation in France? Desegregation trends and inequality along ethnoracial lines. Social Science Research, 73, 45-62.

Newman, B. J., \& Velez, V. (2014). Group size versus change? Assessing Americans' perception of local immigration. Political Research Quarterly, 67(2), 293-303.

Perrineau, P. (1997). Le symptôme Le Pen: radiographie des électeurs du Front national. Paris: Fayard.

Pettigrew, T. F. (1998). Intergroup contact theory. Annual Review of Psychology, 49(1), 65-85.

Rathelot, R., \& Safi, M. (2014). Local ethnic composition and natives' and immigrants' geographic mobility in France, 1982-1999. American Sociological Review, 79(1), 43-64.

Rojon, S. (2013). Immigration and extreme right voting in France: A contextual analysis of the 2012 presidential elections. International Migration Institute Working paper 79. Oxford: University of Oxford.

Rydgren, J., \& Ruth, P. (2013). Contextual explanations of radical right-wing support in Sweden: Socioeconomic marginalization, group threat, and the halo effect. Ethnic and Racial Studies, 36(4), 711-728.

Rydgren, J., \& Tyrberg, M. (2020). Contextual explanations of radical right-wing party support in Sweden: A multilevel analysis. European Societies, 22, 555-580.

Safi, M., \& Simon, P. (2013). Les discriminations ethniques et raciales dans l'enquête trajectoires et origines: Représentations, expériences subjectives et situations vécues. Economie et Statistique, 464, 245-275.

Savelkoul, M., Laméris, J., \& Tolsma, J. (2017). Neighbourhood ethnic composition and voting for the radical right in The Netherlands. The role of perceived neighbourhood threat and interethnic neighbourhood contact. European Sociological Review, 33(2), 209-224.

Scheepers, P., Gijsberts, M., \& Coenders, M. (2002). Ethnic exclusionism in European countries. Public opposition to civil rights for legal migrants as a response to perceived ethnic threat. European Sociological Review, 18(1), 17-34.

Schelling, T. C. (1969). Models of segregation. The American Economic Review, 59(2), 488-493.

Scheve, K. F., \& Slaughter, M. J. (2001). Labor market competition and individual preferences over immigration policy. Review of Economics and Statistics, 83(1), 133-145.

Shields, J. (2013). Marine Le Pen and the 'New' FN: A change of style or of substance? Parliamentary Affairs, 66(1), 179-196.

Sipma, T., \& Lubbers, M. (2018). Contextual-level unemployment and support for radical-right parties: A meta-analysis. Acta Politica. https://doi.org/10.1057/s41269-018-0120-2.

Steinmayr, A. (2016). Exposure to refugees and voting for the far-right: (Unexpected) results from Austria. IZA discussion paper, Institute for the Study of Labor, http://ftp.iza.org/dp9790.pdf.

Van der Brug, W., Fennema, M., \& Tillie, J. (2005). Why some anti-immigrant parties fail and others succeed: A two-step model of aggregate electoral support. Comparative Political Studies, 38(5), 537-573.

Wagner, U., Christ, O., Pettigrew, T. F., Stellmacher, J., \& Wolf, C. (2006). Prejudice and minority proportion: Contact instead of threat effects. Social Psychology Quarterly, 69(4), 380-390.

Publisher's Note Springer Nature remains neutral with regard to jurisdictional claims in published maps and institutional affiliations. 